\title{
Solidary personalism, (T)transcendence and God in Irigaray's Thought
}

\author{
Bojan Žalec \\ University of Ljubljana, Slovenia
}

\begin{abstract}
The author deals with Irigaray's ideas in the context basically described at the one hand by the terms nihilism and instrumentalism, and by solidary personalism at the other. Solidary personalism is defined as a view which considers flourishing of every person as the main value. Its opposites are nihilism (everything is leveled hence also human persons have no special, distinguished value,) and instrumentalism which takes persons as means. The author lists several positive or negative factors which effect upon cultivation and spreading of personalism or its opposites, and in this light evaluates Irigaray's ideas. The main disagreement concerns the attitude toward (the idea of) objective (independent of humans) truth and transcendent God (in the sense of a person radically different from any human person). The author thinks that both ideas as accepted are important pro-personalist factors. The textual evidence from Irigaray suggests that she doesn't accept them. Otherwise Irigaray's view might be characterized as solidary personalist in several most important respects, and as an immense and original contribution to it. The author claims that at one hand there are no central or inherent reasons in Irigaray's view that would block the acceptance of objective truth and humanly transcendent God. Yet as he considers both ideas as positive factors regarding the cultivation of solidary personalism their denial represents certain tension or incoherence in Irigaray's view. Hence the author concludes that the acceptance of them would make Irigaray's view more coherent and more clearly solidary personalist.
\end{abstract}

Keywords: Irigaray, solidary personalism, (T)truth, God, human divinity, secularist theology, spiritualization 


\section{Introduction}

My own general and basic view - which provides the background of all my consideration in this paper - can be best described with the term solidary personalism.

The word personalism refers to an important stream in the European and American philosophical thought which has inspired Christians and humanists. Its core is the investigation and defence of a person (personality), her/his nature, depth, value and meaning. Opposing to individualism on the one hand and collectivism on the other, personalism stresses uniqueness and a unique value of every person, the meaning of interpersonal relations, and God who connects all persons and is himself a Person. Personalist findings about the nature of a person have important consequences for our views in ethics, politics, education and religion. Yet our knowledge about the history of personalism is still very deficient. Bengtsson (2006) argues that personalism appeared already in the $18^{\text {th }}$ century, that it was the central international stream of thought in the $19^{\text {th }}$ century, and that it is more characteristic for the $19^{\text {th }}$ than for the $20^{\text {th }}$ century.

There are many kinds or forms of personalism. We can distinguish between substance personalism and relational personalism (cf. Bengtsson op. cit.). Solidary personalism - the term is my neologism - is a form of relational personalism. Let me mention just some thinkers whose work is especially important as a source, origin and foundation of solidary personalism: Christian faith and (intellectual) tradition in general, works of Søren Kierkegaard, Nikolay Berdiaev, Max Scheler, Martin Heidegger, France Veber, José Ortega y Gasset, Milan Komar, Emmanuel Mounier, Martin Buber, Eric Voegelin, Ludwig Wittgenstein, Emmanuel Lévinas, Zygmunt Bauman, Hannah Arendt, Edith Stein, Pope John Paul II (Karol Wojtyła), Józef Tischner, Luce Irigaray, Paul Ricoeur, David Hollenbach, Alasdair MacIntyre, Charles Taylor, Martha Nussbaum, Hubert Dreyfus, René Girard and others (this list is of course not exhaustive).

According to solidary personalism persons are essentially relational beings and must be treated in their concrete situation and historical perspective. Person is a transcendent being which can be mastered neither ontologically nor epistemologically. Additionally, persons are in principle equal regarding their right to cultivate their singularity or individuality.

Solidary personalism can be maybe best understood when compared with nihilism and instrumentalism which form its antipode (cf. Žalec 2011a). Nihilism is a condition of an individual, a group, a society, culture in which experiential and intellectual horizons everything is leveled. A nihilistic subject cannot honestly experience one thing or being as more valuable than any other. As nihilism is practically impossible, it usually transforms into some kind of instrumentalism. 
Instrumentalism is the attitude that does not regard a particular person as a goal, but (at best) just as a means. To the contrary, for a personalist, every person is always a goal. The main aim of a solidary personalist is flourishing of every person. The key moment of his/her attitude is the acceptance and respect of the transcendence of every person (including his/her own). We can discern several aspects of this transcendence: epistemological, moral and - according to religious views - also metaphysical. Person also transcends every identity, especially the collective one.

An inherent part of solidary personalism is solidarity with concrete persons. Solidarity is a conditio sine qua non of good life (of individual, of society and of community). (Cf. Žalec 2011b) By solidarity I mean not just a kind of economic solidarity but the mutual participations of persons on their lives including all aspects. The central moment of such solidarity is what David Hollenbach (2003) called intellectual solidarity, the participation on the experience of the other. According to the personalist attitude I have in mind we should achieve as much as possible of solidarity and should try our best to participate on the lives of others and to enable others to participate on our lives.

Another central moment of solidary personalism is dialogic universalism¹. It includes the aspiration for universally valid ethics, which however should be developed and established through dialogue between all concerned parties. There are important universals common to all people that provide the basis on which a consensus about universal ethics can be reached, despite the fact that actual lives of cultures and individuals have their own particularities. The endeavour for experiential and intellectual solidarity is a crucial constituent of dialogic universalism (Hollennbach 2003). Intellectual solidarity is the realization of genuine dialogue. Dialogic universalism is a reasonable and realistic stance, as there are factual universals of any human condition. We can capture some evidence for the last thesis and reflect on the possibility of pursuing the common global good in the spirit of dialogic universalism by applying the capability approach, pioneered by Amartya Sen and originally philosophically developed by Martha Nussbaum (for more about dialogic universalism and capability approach see Žalec 2008). Dialogic universalism is compatible with and can be supplemented by the belief in a universal common core of the (main) global spiritual and moral traditions, the so called world ethos (Küng 1991), which consists of facets or moments of solidary personalism.

Dialogue and solidarity are origins of good human life at all its levels, areas, forms, times and places. Violation of dialogue and solidarity is fatal. Yet we should

1 The term was first used by Hollenbach in 1979 (see Hollenbach 2003, 152, n. 23). 
be careful even by our efforts to cultivate solidarity. Despite the importance of (intellectual) solidarity we should not forget that there is also the other side of the coin: the belief that total (intellectual) participation in the (intellectual) life of another person is possible - or even striving for it - could be dangerous, because it could mean that we actually do not believe anymore that such a person is transcendent and, hence, we renounce the personalistic attitude towards him or her. We should aim to participate in the life of the other however not at the expense of disrespecting his or her transcendence. The belief that we can totally participate in the experience or life of the other is a dangerous illusion. Solidary personalists always treat themselves and the other as in principle transcendent (Žalec 2011a).

The most appropriate attitude towards (cultural) identities might be called - using epistemological terms - critical realism (cf. Žalec 2011b, 112). Neither the attitude that takes identities as untouchable or overestimates their importance or superiority, nor the stance that diminishes their importance - or even considers them as something that should be destroyed or eliminated because they are only used for some bad aims, to instrumentalize people's attachments, affections, emotions for certain goals (political, economical...) - are proper. Neither the subordination of some individual concrete persons to some (collective) identity nor the "nihilistic" attitude to identity, are acceptable. Collective or moral identities $^{2}$ are necessary for flourishing of persons, they have their irreplaceable value that should be respected yet they should also develop and transform themselves. Their good and acceptable elements should be accepted and some other parts should be discarded or modified.

Nihilism and instrumentalism are the fundamental problems (of our age). They seriously hinder or even stop the cultivation of dialogue, solidarity, approaching other as other etc. All mentioned goods and their relatives are essential moments of solidary personalist attitude, ethics, relationships and existence. The fundamental (ethical) task (of our age) consists in (finding the ways for) the sufficient and adequate diminishing or limitation of the scope of the instrumentalist reason and practice.

I use solidary personalism as the basic ethical measure. Hence I use the negative/positive factors of solidary personalism also as the criteria for ethical evaluation of several attitudes and phenomena.

In this paper I investigate what kind of personalism Irigaray pleads for. I present the theses of solidary personalism and then compare them with the relevant Irigaray's stances found in her work. The analysis of the correspondence

2 For further elucidation of the concept of moral identity see Strahovnik (2011, 69-72). 
or violation of the ethics of solidary personalsim, represents the basis of evaluation of Irigaray's viewpoint in this paper. The main disagreement concerns the attitude toward (the idea of) objective (independent of humans) truth and transcendent God (in the sense of a person radically different from any human person). The author thinks that both ideas as accepted are important pro-(solidary) personalist factors. The textual evidence from Irigaray suggests that she doesn't accept them. Otherwise Irigaray's view might be characterized as perfectly solidary personalist in several most important respects and as an immense and original contribution to solidary personalism. I claim that at one hand there are no central or inherent reasons in Irigaray's view that would block the acceptance of objective truth and humanly transcendent God. Yet as I consider both ideas as positive factors regarding the cultivation of solidary personalism their denial represents certain tension or incoherence in Irigaray's view. Hence I conclude that the acceptance of them would make Irigaray's view more coherent and more clearly (pro)-(solidary) personalist ${ }^{3}$.

\section{Anti-instrumentalist factors, cures and anti-dopes}

Let us now list some positive factors of solidary personalism and compare them to Irigaray's work.

1. Accepting the idea of objective (human independent) (T)truth.

2. Cultivation of deep or background understanding, experiencing, valuing, cultivation of deep identity and innerness, of humanity, of human beings as humans. ${ }^{4}$

From here on I use also a (shorter) term personalism for solidary personalism.

4 The proper basis for personalism is set already by Irigaray's stressing of the fundamental importance of the cultivation of humanity and of the importance of innerness:

"The greatest challenge that confronts us today concerns the evolution of humanity as such. In my opinion, the matter is no longer one of proving capability of mastering the world - be it the moon or the most minute particle - but of questioning about what or who is a human being and of seeking to reach, become and accomplish our humanity. Humans have searched for these outside themselves through dominating the world and constructing worlds of their own. The time has arrived for turning to ourselves and for undertaking an inner journey. For such a task, we precisely have to leave the 'facing us' which has determined our logic of representation and our discourses or acts. I think that recognizing the other as other and seeking to meet and coexist with respect for our difference(s) could be our guide for reaching another stage of our becoming humans." (Irigaray 2008, 82)

Regarding the identity, there is no doubt about the importance of the cultivation of deep identity for Irigaray, especially of the sexual identity:

"As far as I am concerned, 'becoming woman' or 'becoming a woman' corresponds to cultivating my own identity, the identity which is mine by birth."(Irigaray 2008, 79) 
3. Accepting the crucial importance of what can't be rationalized, totalized and mastered, renouncement of the idea that humans can (and may) control everything. ${ }^{5}$

4. Acceptance of transhuman and "superior" (compared to humans) personal transcendence, that is God.

5. Idea that every human being is an image of God (Imago Dei).

6. Deontological morality. ${ }^{6}$

7. Importance of body, of bodily contact and gathering.

8. Spiritualization (including of body (Russian personalists, Gandhi)) ${ }^{7}$.

9. Dialogue.

10. Communication.

11. Community.

12. Elimination of negative competitiveness.

13. Renouncement of individualism.

14. Solidarity.

15. Sensibility.

16. Love.

17. Cultivation of art. $^{8}$

According to Irigaray one can't cultivate his or her identity without recognizing other as the other: "I recognize you is the/one condition for the existence of I, you and we." (Irigaray 2004, 8)

5 Actually the idea that everything of importance can in principle be mastered is incompatible with personalism that accepts the (nontrivial, important) transcendence of every person. In the first chapter of her Key Writings titled "You Will Never Be Mine" Irigaray wrote:

"I recognize you means that I cannot know you in thought or in flesh. The power of a negative remains between us. I recognize you go hand in hand with: you are irreducible to me, just as I am to you. We may not be substituted for one another. You are transcendent to me, inaccessible in a way, not only as ontic being but also as ontological being (which entails, in my view, fidelity to life rather than submission to death.) Between us a transcendence always subsists, not as an abstraction or a construct, a fabrication of the same to ground its origin or to measure its development, but as the resistance of a concrete and ideational reality: I will never be you, either in body or in thought.

Recognizing you means or implies respecting you as other, accepting that I stop before you as other before something insurmountable, a mystery, a freedom that will never be mine, a subjectivity that will never be mine, a mine that will never be mine." (Irigaray 2004, 8)

6 According to Irigaray, man or woman has an obligation to become his or her gender (see Irigaray 2004, 10).

7 "Instead of the repression of spirit on body, which is usual in our tradition, I prefer the transformation of body as living matter into spiritual matter." (Irigaray 2008, 80)

8 "Art then recovers a place that Western logic has too neglected in our exchanges, as it is also the case with concern about the present. Dialogue is always a creation which takes place in a meeting between two persons; it cannot be reduced to repetition of something already said in another time, another context." (Irigaray 2008, 33) 
18. Attitude of spiritualized pragmatism ${ }^{9}$ and acceptance of plurality of life principles.

19. Corresponding level for every entity or being.

20. Active civil society.

21. Spiritual truthful elites.

22. Consistent, consequent, coherent and universal non-instrumentalist stance and acting. ${ }^{10}$

23. Cultivating of the approaches of dialogic universalism and World Ethos (Hans Küng).

24. Realistic and factual respecting, recognizing, accepting and approaching the other as the other, her or his identity, tradition, subjectivity, creating a place for the other or for a stranger. ${ }^{11}$

25. The proper anthropology or transcendent personalism:

a) Apophatic anthropology or transcendent anthropology (including accepting of a stranger in ourselves). ${ }^{12}$

b) Realistic, yet not too negative anthropology (negative anthropology as a self-fulfilling prophecy and a basis for non-democratic and non-developing doctrines and regimes).

c) Proper understanding of humanity or of human nature and of the human being as a human being.

9 Spiritualized pragmatism and personalism are not mutually exclusive. So it is not a surprise that some authors label Irigary as a kind of ethical pragmatist (cf. Škof 2010, 137). See Irigaray 2008, 82 as, confirming Irigaray being a personalist in this respect.

11 "I think that recognizing the other as other and seeking to meet and coexist with respect for our difference(s) could be our guide for reaching another stage of our becoming humans." (Irigaray 2008, 82) This point is also the reason for one of the most fundamental Irigaray 's criticisms of our culture:

"The transcendence of the you as other is not yet, really, part of our culture. At best, the other is respected in the name of tolerance, is loved in God, is recognized as an equal or a fellow human. But that does not yet amount to perceiving and respecting the irreducibility of the other, to recognizing the irreducible difference of the other in relation to me. /... / Dominating, controlling has been taught to us as the realm of reason more than accepting our limits, in order to live together, to coexist, to co-create even, with who or what exceeds us, extends beyond us, remains irreducibly exterior and foreign to us.

We have learned to think starting from a certain number of dichotomies between sensible and intelligible, nature and spirit, body and soul, subject and object, etc. And we do not know how to transform such categories in order to attain a culture of alterity, of relation with the other as such, of acknowledgement of the other as irreducible to us, in order to make an alliance with him, or with her, in the respect for our respective values or limits.

At best, we are sometimes good patriarchs or good matriarchs. But this is genealogical behavior, implying nature, still avoids meeting with the other: the man or woman that I must horizontally recognize as equivalent to me, in the radical respect of his or her difference(s)." (Irigaray 2002, 126)

12 The true hospitality consists of accepting of the other as the other, of a stranger. Only a person with the transcendent attitude toward herself is capable of recognizing a stranger and unknown in herself, and (because of this) capable of hospitality toward a stranger in some other persons. Cf. also Kristeva 1991. 
26. The importance of proper understanding of other sex and of proper relationship to it..$^{13}$

27. Non-spatial or non-bodily understanding of the spirit (St. Augustine ${ }^{14}$ ).

28. Non-objecti(fy)ing thinking (spirit is not an object).

29. Idea of immortality (Gilson's argument against generic conception of man) ${ }^{15}$.

30. Respecting of human rights.

31. Acceptance of vulnerability, exposure ${ }^{16}$, taking risk, sacrifice.

32. Awareness of mutual interdependence (about illusion of self-sufficiency).

33. Imitatio Christi.

Before I continue let me quote a passage from Irigaray's recent article that nicely summarizes some central moments of her view and efforts:

"I hope that I paved the way for understanding that ethical gestures toward the other cannot be inspired by mere moral standards, that can vary between the cultures and through which we dialogue with ourselves more than with the other. To be ethical rather involves that we respect the world of the other as well as our own, the place where his or her lives and their manner of relating to themselves, to the world and to the others. The undertaking is to build a culture in which the requirements for relating between people at a human level represent the priority. And the question is not, as it is too often claimed in our times, of sharing needs in order to attain sharing desire, because the first gesture, then generally substitutes for the second and prevents our becoming human adults capable of sharing in difference. The matter is rather of cultivating desire and love with respect for each singularity, and this behavior little by little, directly or indirectly, will result in solving the problem of needs for all." (Irigaray 2010, 23)

13 "Now our behavior with respect to difference of races, of cultures, of generation, etc. often results from a lack of cultivation of our sexual instincts, our most basic instincts in relating with the other(s). Another thing: the cultures and traditions are, in great part, constructed starting from sexual and sexuate difference, at the level of the genealogies or marriages and alliances. How could it be possible to distinguish a culture with respect to our own without taking into account the different way of dealing with sexes or genders in this culture? And for example: Are not the problems about the Islamic veil sexual or sexuate problems? And could not the separation of private and public life contribute to the subjection of women, as women working towards the liberation in the 1960s and 1970s claimed?" (Irigaray 2008, 82)

14 See for instance the seventh book of his Confessions.

15 In a nutshell, the argument is the following: In the case of incorruptible (immortal) individuals the individuals themselves, not only their species, become the first intentions of the nature or the Creator. See Gilson 1991, ch. X.

16 Kierkegaard described his age as nihilistic. He didn't use that term but the phenomenon of nihilism is detected. Our age, claimed Kierkegaard, is the age that levels all things (cf. Kierkegaard 2009, 84). The context or the background of the age is such that things cannot appear as better or worse. Among the characteristics of his nihilistic age he listed we find also the lack of exposure and avoiding the risk (cf. op. cit., 68). 


\section{The origins of spiritual transformation}

Nowadays many talk about the need for solidarity, dialogue and some also about the need of a spiritual transformation. Some partisans of Marxism see the root of evil in the capitalistic liberal democracy. However it may be, even to many of instrumentalists is clear that our civilization develops in wrong direction and that it needs to transform. The dimensions of the crisis and the harms done can't be ignored any more. The economical and ecological crisis only intensifies and fortifies this comprehension.

There is a very big variety of trends in current thought represented by thinkers who are aware of the problem of absence of spirit in our lives: from theistic authors to representatives of more or less atheistic viewpoints (Peter Sloterdijk, Ulrich Beck, Slavoj Žižek (his “theological” turn $\left.{ }^{17}\right)$ ). ${ }^{18}$

Sloterdijk is intensely dealing with the indispensability of a zeal, thymos, faith, religion, with the idea of post-zealotic attitude (Jan Assman (counter-religion) (see Sloterdijk's books Zorn und Zeit and God's Zaeal)). Beck's book Der eigene Gott might in many respects be considered as a sociological application and supplementation (and even clarification) of the ideas developed in the two mentioned Sloterdijk's books. Sloterdijk is pleading for the creating of a more airy (religious(like)) atmospheres like they already existed in the past. ${ }^{19}$ Irigaray to the contrary speaks about the new age, the age of sprit or the age of breath that is only coming.

Deeper thinkers of the $20^{\text {th }}$ Century grasped our condition and its drawbacks of course already much earlier. William James, Gandhi, Heidegger (Gelassenheit). Yet even before Heidegger and partly simultaneously with his time, another stream of spiritualistic philosophical thought was present between the East and the West. Heidegger's imanentist yet "apophatic" thought (respecting the transcendence of Being and stressing the importance of non-objective comprehension of Being) can be fruitfully combined with the thought of Russian personalists (Solovyov, Berdyaev) and their refusal of objectivistic mind as appropriate for grasping the

17 For Žižek’s »Christology« see Depoortere 2008.

18 Even Jürgen Habermas, to whom any religious musicality can hardly be ascribed, has started to stress that there are things that religion and Christianity can offer and which are needed (cf. Habermas \& Ratzinger 2006, and Habermas et al. 2010).

19 Peter Sloterdijk searches in his own way for spiritualization. Sloterdijk is also a kind of apophatic thinker and one of few famous European male philosophers who clearly argued for the superiority of the feminine knowledge (cf. Sloterdijk 1988, ch. 3, esp. pp- 84-85). He develops the idea of non-zelotic religion, but the main hope he lays on the cultural science(s). Yet, the problem is that cultural scientists themselves need spiritualization, which gets more and more lost (and this loss is the most fundamental internal danger for the important presence of humanities). Their views themselves must be enriched in order that their science can offer a ground for a spiritualized society. 
areas belonging to spirit. They stressed the importance of the spiritualization of body, flesh and the nature. They saw quite early the nonsolid grounds of the European humanism which show up very clearly today.

The common denominator of all those (and many others) efforts and appeals and findings can be summarized in one common recognition or demand: we need spiritualization. We must find a way to spiritualize our private and social life in all their segments. We cannot afford any longer the life in an "enchanted" world. But how can we do it? Where to start?

\section{Proper understanding of woman(hood) as the foundation of the needed spiritual transformation}

Luce Irigary has been for a long time aware of the importance of the spiritualization and has already for decades developed and presented her original answer to the questions set above. Where to start? Her answer is clear: by proper comprehension and relationship toward woman(hood).

Irigaray's fundamental efforts are devoted to the overcoming of the mono-subjective view. The question of approaching the other as other is the central topic of her work. She stresses that we must be careful when treating the other as such and she pleads for the model of two as opposed to the model of one. The paradigm of the first is sexual difference. She claims that the feminine subjectivity is irreducible to the masculine subjectivity. She approaches the characterization of the feminine world as different from the masculine one with respect to language, body, work, nature and the world of culture. She criticizes (Western) philosophy and culture as mono-subjective, mono-sexualized, patriarchal and phallocratic. The suspension of the authority of one is according to Irigaray a necessary condition of women's liberation, of ethical behavior with respect to the other, of democracy and of philosophy proper. The shift from singular subject to two, which is needed for the affirmation of women's autonomy, is a philosophical and a political task of women.

\section{Is Irigaray's theology a secularist one?}

I think that Iragary's stance might be characterized as solidary personalism. ${ }^{20}$ A person and his/her flourishing is one of the central if not the highest value in

20 In that respect her view resembles the view of Martha Nussbaum and differs from the views of some other secular egalitarian and instrumentalist "theological" thinkers, like for instance Žižek. 
her view. She stresses the importance of dialogue and proper relationships but on the other hand she also pleads for the respect of irreducible individuality and particularity of every being. She is never tired of pointing out the importance of treating the other as the other, and of respecting of his/her transcendence - in flesh and spirit - as a necessary condition for it. However, the claim that Irigaray's view is personalistic, yet secularist (or immanentistic) seems justified:

"Human identity and divine identity have been artificially separated. And we generally fail to recognize that becoming divine corresponds to becoming perfectly human." (Irigaray 2004, 193)

From what is said above it does not follow that there is no God since concepts of being divine and of God are not totally identical. However, one can think that there is no place for God in the sense of being superior to human person in Irigaray's horizon. In that case the (central) question appears relevant for Irigaray: What's wrong (if anything) with transcendental theology?

In searching for the answers in Irigaray's case we should ask: Why there can be no God according to Irigaray? It seems to me that the reason might be: Because God is higher of any human person and of any female person in particular. There remains only God in the sense of a spiritualized human. But, we may note: 1 . To such God we can't pray for a prayer is a cult and (than) an appeal; 2. Do we not deal with a kind of instrumentalist stance when we say that we pray when we are connected with just another human person? There is an analogy between love between two persons and a prayer, still they are different and such "instrumentalization" can't be successful, for there are absent the crucial reasons for it: the sanctioning of otherwise irreparable justice. This doesn't imply that faith is reduced to a pure teleological dimension but as any value it has both dimensions: deontological but also teleological. From the other aspect we might maybe say that in such a case we deal with a kind of pantheism as opposed to dualism. We are gods when we are spiritualized beings in a proper relationship with the other. Irigaray says that through a prayer we gather in us. ${ }^{21}$

Hence I think that one of the central virtues that should be dealt with in the frame of Irigaray's opus and philosophy is the virtue of humility. Humility was proclaimed as the basic virtue by Iris Murdoch in her Sovereignty of Good. The consideration of that virtue can maybe throw more light on, as it seems to

21 Such a view reminds me on Max Scheler's position in his work Man's Place in Nature. Scheler speaks about the becoming god who needs a man for his being or becoming. Scheler is a kind of personalist and describes a person not as an object but as something we gather around. 
me, Irigaray's ground stance which is the refusal of any entity or being which is superior to human person. It seems that this is not the result of Irigaray's thinking path but rather her starting point.

\section{Sexual identity}

Let us now consider the topics of sexual identity and meaning of sexual relationship. Personalist view (Solovyov (1996), Volf (1996)) claims the non-existence of the independence of the sexes. According to it, it is reasonable to interpret the Bible as supporting this view as correct (Volf 1996). This position claims the difference between sexes but at the same time it posits the identity of one sex as already internal to the identity of the other (ibid.). In this respect Volf $(1996,189)$ quotes Irigary sentence from the last page in her I love to you: "Your retreat reveals my existence, as my withdrawal is dedicated to you." This position can be further illuminated and supplemented if we look at the accounts of the meaning of sexual uniting. We can distinguish the following accounts (Berdyaev, 1944):

1. Having children, procreation of the species;

2. Satisfaction of needs by means of other person;

3. Personalist view (Solovyov, Berdyaev): the meaning of sexual uniting is the uniting with the beloved person, in reaching man's or woman's fullness, completeness, perfection, realization through such a uniting.

I think it's safe to claim that the personalist claim (3) is also what Irigaray believes.

\section{The age of breath}

In her essay The age of breath Irigaray developed the following relevant thesis: 1. Only woman is able to lead man to his being and to his natural environment. ${ }^{22}$

22 "In this new age the relation with nature will be changed. Indeed, the woman's almost natural disposition to the divine does not tolerate the domination over nature, over the world, neither any arrogance towards them.

The removing of woman from herself originates in a man's domination over nature - micro- or macrocosmic -, as we can read in our mythologies, and still in the tragedy of Antigone by Sophocles. Forgetting historically his way, for occidental man, results from a similar dominion over nature, and from a loss of identity for the woman, the only one who is able to lead man again to his being, and to his natural environment." (Irigaray 2005, $11 \mathrm{E}$ ) 
2. The path from nature to grace requires humility to spiritualization that is to becoming divine. ${ }^{23}$

3. We must return to the breath before and beyond any representation and discourse. The accomplishment of the perfect realization of humanity demands the cultivation of breath as the divine presence:

"Centered on the divinization of humanity incarnate and not on any representation of divinity - images, various figurations, abstract ideals, dead words: all kinds of idol -, our epoch has to return to awareness and to a cultivation of the breath before and beyond any representation and discourse. The accomplishment of humanity, its perfect realization, requires the cultivation of one's own breath as divine presence, in ourselves and between us." (Irigaray 2005, 16 E)

4. God is us; we are divine if we are perfect men or women:

"This necessitates a God who does not stay outside of humanity and finally opposes it - for example in its carnal desire. This demands a God who coincides with the accomplishment of humanity itself, with its spiritual transmutation or transfiguration. God is us, we are divine if we are woman and man in a perfect way." (Ibid.)

5. The divine lived in such a manner leads to the redemption of love, including carnal love:

"The divine heard and lived in such a manner opens up the path to a redemption of love, including carnal love that is part of humanity if it is cultivated, spiritualized and not left to the possessive or a reproductive instinct." (Ibid.)

6. The third age (the age of breath) is characterized by the respect of differences between us (not only between us and an Absolute). Remaining of the spirit as a soul in flesh is a necessary condition of the realization of the divine in humanity. ${ }^{24}$

23 "The path which goes from nature to grace requires to woman to be attentive, available and receptive to a sort of energy, of light, of comfort which cannot be mastered. It is necessary to let grace be. In this way the meaning of the word humility can be heard, too often used against and not in favor of the woman's spiritual becoming. It is not with respect to the man-made world that in the woman must be humble, it is not the cosmic or corporeal destruction that she has to say 'yes' or 'amen', but to spiritualization, a becoming divine of the immediate energy within her as well as outside her." (Irigaray $2005,11 \mathrm{E})$

24 "The epoch of the alliance between women and men, the epoch of the horizontal union between women and men, the epoch of the horizontal union between sexes or the genders, the third age, overcomes the dependence on genealogy. Humanity here reaches its 
Remaining faithful to the spirit is a way to the bridge between different traditions. Woman is a privileged mediatrice to do that, the divine gives energy for such gestures, the divine is the love for the other as the other, the praise of the nature as nature..$^{25}$

\section{The divine does not imply the existence of God:}

"But the divine does not necessarily signify for woman that an entity called God exists. The relation of the woman with Good seems both subtler and more incarnated, less reduced to an object, even sent beyond our world. Women's God does not appear as a hypostasis of another world we have to believe in. That is to say, a God appropriate to the feminine may not paralyze the fluidity of the breath or of the grace through a fixed identity or fixed commandments, on pain of depriving the woman of the relation with her soul. And that would remove the way of breath, and maybe life itself, be it natural or spiritual, from entire humanity." (Irigaray 2005, 19 E-20 E)

\section{The (main) difficulty of a woman may be overcome by the cultivation of breathing:}

"The difficulty for a woman is to remain both in the fluidity and in herself, in her interiority. Also here, a possible way for uniting these two necessities lies in the cultivation of breathing, in a culture of the breath. I do not know if there is another path, but this one

maturity, becomes adult and capable of responsibility towards itself and towards other, in respect of the difference, of differences, which exist here and now between us, and not only between us and an Absolute of another world.

An absolute difference takes place first of all between us and, thanks to it, we may escape animality, and all sorts of subjection and slavery, and become divine. The acknowledgement of this difference corresponds to the gesture of consciousness or conscience, both spiritual and concrete. It allows the spirit to remain soul in the flesh: a necessary path to the accomplishment of the divine in humanity." (Irigaray 2005, $17 \mathrm{E}$ )

25 "To remain faithful to the spirit with respect for difference, for differences, also grants access to an exchange between the spiritual traditions, before or beyond the figurations of the rituals that they have given to themselves to rejoin their divinity or divinities. One can think of the three traditions of the Book here, but also of the traditions of the Near, the Middle and the Far East, to evoke only those I know a little. For building bridges between different traditions, women are privileged mediatrices. For them, neither dogmas nor rites, and even not representations are indispensible to approach the divine. The contemplation of the universe, as well as the contemplation of the other, the respect for that which exists outside of oneself, is often more appropriate to their becoming spiritual, to a culture of interiority adequate to them.

The divine gives energy for such gestures, and the divine rises from them as well. Divine is the love for the other as other, divine is the praise of nature as nature." (Irigaray 2005, $18 \mathrm{E}-19 \mathrm{E})$ 
can be (re)discovered and practiced. It grants to the woman autonomy as well interiority, two indissociable dimensions of subjectivity." (Irigaray 2005, $20 \mathrm{E}$ )

\section{Critical remarks on Irigaray}

The main problem of Irigaray's position is her non-acceptance of God as a different and superior person compared to human persons. According to Irigaray human persons, when perfectly realized as themselves, as women and as men, are divine. And that is all: there is no other personal non-human and superior divine being.

Such an "atheistic" stance implies at least the following fundamental problems which bear their effects upon the possibility of the - as it seems main - obligation or value in (both) Irigaray's and personalist horizon: the perfect realization (or flourishing) of every concrete person. The problems are the following:

1. The problem of Irigaray's conception of truth.

2. Impossibility of a man being an image of God (since there is no God).

3. Impossibility of true prayer.

4. Problems with immortality.

In the "Introduction" to her Conversations Irigaray actually reflects on the way to reach the truth. According to her this way is a dialogue which presupposes and involves concrete and engaged, non-neutral persons, and not a kind of aseptic and neutral formalism which dominates in many contemporary intellectual circles as the only guarantee of truth.

Yet Irigaray regrettably doesn't believe in the universal and super-sensible truth that exists outside of ourselves and is valid for all times and spaces (op. cit., $\mathrm{x}$ ):

"Unfortunately, most of us have stopped believing in a supra-sensible truth that exists outside of ourselves and would be valid for all people in all spaces and times. Now truth results from who or what we are, from our experience(s), from our journey, among other things from our advancement in the recognition of the other as the other and in our ability to exchange with such an other in mind. The quality of conversations, which are gathered in this book, could be assessed, not according to the degree of asepsis and disengagement, but according to the degree of attentive respect for the other. That is, according to the involvement of the person who enters into dialogue in the exchange itself; instead of their neutralization for the benefit of a truth indifferent to the one and the other, a truth that they would attempt to reach in the name of a scientific asceticism beyond any personal involvement." (Op. cit., xi)

As it seems, Irigaray doesn't keep apart the way to reach the truth and the truth itself. I agree that dialogue is the proper way to existential truths. I also agree that the truth we know is always incomplete, partial and in this sense subjective. 
Yet this doesn't imply that there is no universal, complete and objective truth at which we could imperfectly participate and make progress in this participation in a process that includes overcoming and elimination of our errors, false beliefs, prejudices etc. Without objective and transcendent truth no argument against nihilism or instrumentalism is possible. The topic of truth is of crucial importance in the struggle against instrumentalism (see Žalec 2011a).

According to Irigaray, prayer is a daily necessity. Yet, we may add, if there is no God in the sense of a personal being superior to man prayer doesn't really make sense, in short, there is no true prayer. For we shouldn't confuse prayer with some technique intended to improve our well being (see the section titled "Is Irigaray's theology a secularist one?" above, also Žalec 2007).

To the last, fourth remark: the idea of literal individual immortality doesn't make much sense in the immanentist or secularist horizon.

At the end of this section maybe it is worth to add also the following general remark: every secularist theology involves a danger to transform in a kind of gnosticism in Voegelin's sense of the term (cf. Voegelin 1987). Regarding the theological and anthropological reflexion and catastrophic historically evidenced "accounting" of gnostic or secular theologies (cf. for instance Voegelin (op. cit.), also Žalec 2014b) we shouldn't underestimate their harmful potentials at all. The same is true about the refusal of the acceptance of a transcendent God (and his call) in general (cf. Pope John Paul II 2005; Bellinger 2001; 2008; Žalec 2014a).

\section{Reasons for Irigaray's refusal of a transcendent God}

Why does Irigaray refuse the idea of a transcendent person who is however not a human person, in short God? One answer is that a human person in case of accepting God is subordinate to him. But that is not necessary as the example of Berdyaev shows who considered the thought of refusing God dreadful and tremendous but at the same time stressed that the relation between God's person and human person is not properly understood in terms of causation or subordination but rather in terms of existential encountering. (Cf. Berdyaev 1944) And if we understand the existential encountering as participating at the other yet also as transcendent it is exactly this what Irigary refuses as possible in case of accepting God. Let us quote again her words:

"The transcendence of the you as other is not yet, really, part of our culture. At best, the other is respected in the name of tolerance, is loved in God, is recognized as an equal or a fellow human. But that does not yet amount to perceiving and respecting the irreducibility of the other, to recognizing the irreducible difference of the other in relation to me. /... /At best, we are sometimes good patriarchs or 
good matriarchs. But this is genealogical behavior, implying nature, still avoids meeting with the other: the man or woman that I must horizontally recognize as equivalent to me, in the radical respect of his or her difference(s)." (Irigaray 2002, 126)

This reminds me of the thesis of personalistically directed Hannah Arendt in her doctoral thesis about Augustine's understanding of love (cf. Arendt 1965): you actually don't love the other human person as the other if you love her/ him because of her/his relationship to God. I think that the following things should be said in this respect. The central idea in all this is that Christian God really is a loving God.

1. The idea of omniscient and all-mighty God is not incompatible with the idea of a human person being (epistemologically) transcendent to God. Thomas Aquinas thought that God is all-mighty only in creating or doing things that are logically possible. Not being able to do logically impossible (contradictory) things doesn't take away anything of His all-mightiness or of His being all-knowing. (Cf. Thomas Aquinas' Summa Theologica, I.25.3; Pessin 2009, 75-77) Loving God who doesn't respect epistemological transcendence of a human person is like a round square, a contradictory being. What is maybe most controversial or non-obviously true in the above argument is the premise that $\mathrm{x}$ having two properties -1 . $x$ loves $y$ and at the same time 2 . $y$ is not transcendent to $x-$ that such $\mathrm{x}$ is contradictory. But as it seems, denying of this premise is not an option for Irigaray.

2. Proper Christian attitude is in principle not subjected to Irigaray's (or Arendt's) criticism: We don't love the (O)other (and ourselves) because of their relation with God, but because we imitate Christ, the loving God, who loves the other as the other. Point. That is everything what in essence is necessary to say. The "commandment" of love is the highest "norm" in genuine Christianity. So we imitate God in loving the other as the other (even in case when the other maybe doesn't "deserve" our love) and not because (s)he is in some (other) relation to God. Thus properly understood Christian love is not incompatible with loving of the other as the other, quite to the contrary. Christ, if anybody showed us how to do it.

\section{Conclusion}

I dealt with Irigaray's ideas in the context basically described at the one hand by the terms nihilism an instrumentalism and by personalism at the other. Personalism was defined as a view which considers the flourishing of every person as the main value. Its opposites are nihilism (everything is levelled hence also human 
persons have no special, distinguished value), and instrumentalism which takes persons as means. I listed several positive or negative factors which effect upon cultivation and spreading of personalism or its opposites and in this light evaluate Irigaray's ideas. The main disagreement concerns the attitude toward (the idea of) the objective (independent of humans) truth and a transcendent God (in the sense of a person radically different from any human person). I think that both ideas as accepted are important pro-personalist factors. The textual evidence from Irigaray suggests that she does not accept them. Otherwise Irigaray's view might be characterized as perfectly personalist in several most important respects and as an immense and original contribution to it. It seems to me that ane hand there are no central or inherent reasons in Irigaray's view that would block the acceptance of objective truth and humanly transcendent God. Yet as I consider both ideas as positive factors regarding the cultivation of personalism, their denial represents certain tension or incoherence in Irigaray's view. Hence I conclude that the acceptance of them would make Irigaray's view more coherent and more clearly (pro)personalist. In other words: There is no need that immensely important Irigaray's thought remains immanentist or inside the frames of secularism. Quite to the contrary. I think that this element can be eliminated practically without any harm to it or without essential transformations. Her philosophy bears for instance a lot of resemblances and common central moments with perfectly transcendent and theistic (in the sense of accepting God as a radically different being from human beings) thought of Russian personalists (Solovyov, Berdyaev) who accept God who is not a human person. So improved it can be even more coherent, important and original modern supplementation of it and of the tradition of the apophatic, spiritualistic (and Godmanhood accepting) Greek, Latin or Western thought (raging from Plato to Heidegger) in general.

\section{References}

Arendt, Hannah. 1965. Love and Saint Augustin (trans. by Joanna Vechiarelli Scott and Judith Chelius Stark). Chicago: University of Chicago Press.

Augustinus. 2006. Confessions. Translated by William Watts. Cambridge (Mass.), London: Harvard University Press.

Beck, Ulrich. 2008. Der Eigene Gott. Von der Friedensfähigkeit und dem Gewaltpotential der Religionen. Frankfurt am Main and Leipzig: Verlag der Weltreligionen im Insel Verlag.

Bellinger, Charles K. 2001. The Genealogy of Violence: Reflection on Creation, Freedom and Evil. New York: Oxford University Press.

Bellinger, Charles K. 2008. The Trinitarian Self: The Key to the Puzzle of Violence. Eugene, OR: Wipf \& Stock Pub. 
Bengtsson, J. O. 2006. The Worldview of Personalism: Origins and Early Development, Oxford: Oxford University Press.

Berdyaev, Nicolas. 1944. Slavery and Freedom (trans. by R. M. French). New York: Charles Scribner's Sons.

Depoortere, Frederiek. 2008. Christ in Postmodern Philosophy: Gianni Vattimo, René Girard and Slovoj Žižek. London \& New York: T\&T Clark.

Gandhi, Mahatma. 1987. An autobiography: or the story of my experiments with truth (trans. by Desai Mahadev). Harmondsworth, Middlesex : Penguin Books.

Gilson, Étiene. 1991. The Spirit of Mediaeval Philosophy (Gifford Lectures 1931-1932, trans. by A. H. C. Downes). Notre Dame, London: University of Notre Dame Press.

Habermas, Jürgen, Joseph Ratzinger. 2006. Dialektik der Säkularisirung. Über Vernunft und Religion. Mit einem Vorwort herausgegeben von Florian Schuller. Freiburg/Basel/Wien: Herder.

Habermas, Jürgen et al. 2010. An Awareness of What is Missing: Faith and Reason in Post-Secular Age (trans by. Ciaran Cronin). Cambridge, UK/Malden, USA: Polity Press.

Hollenbach, David. 2003. Christian Ethics \& Common Good. Cambridge: Cambridge University Press.

Irigaray, Luce. 1996. I Love to You: Sketch for a Felicity Within History (trans. by Martin Alison). New York/ London: Routledge.

Irigaray, Luce. 2002. Between East and West. From Singularity to Community. New York: Columbia University Press.

Irigaray, Luce. 2004. Key Writings (ed. by Luce Irigaray). London/New York: Continuum. Irigaray, Luce. 2005. Die Zeit des Atems/The Age of Breath/L'epoca del respire/Le temps du souffle. Rüsselsheim: Christel Göttert Verlag.

Irigaray, Luce. 2008. Conversations. London/New York: Continuum.

Irigaray, Luce. 2010. Ethical Gestures Toward the Other. In Poligrafi, number 57, vol. 15, pp. 3-23.

Kierkegaard, Søren. Two Ages: The Age of Revolution and the Present Age (trans.by Howard

V. Hong and Edna H. Hong). Princeton, New Jersey: Princeton University Press.

Küng, Hans. Projekt Weltethos. Munich: Piper.

Kristeva, Julia. 1991. Strangers to ourselves (trans. by Leon S. Roudiez). New York: Columbia University Press.

Pessin, Andrew. 2009. The God Question. What famous thinkers from Plato to Dawkins have said about the divine. Oxford: Oneworld.

Pope John Paul II. 2005. Memory \& Identity: Personal Reflections, London: Weidenfeld \& Nicolson.

Scheler, Max. Man's Place in Nature (trans. by H. Mayerhoff). New York: The Noonday Press. Sloterdijk, Peter. 1988. Zur Welt kommen - Zur Sprache kommen. Frankfurter Vorlesungen. Frankfurt am Main: Suhrkamp.

Sloterdijk, Peter. 2008. Zorn und Zeit. Politisch-psychologischer Versuch. Frankfurt am Main: Suhrkamp Verlag. 
Sloterdijk, Peter. 2009. God's Zeal: The Battle of the Three Monotheisms (trans. by W. Hoban). Cambridge, UK \& Malden, USA: Polity Press.

Solovyov, Vladimir. 1995. The Meaning of Love. Esalen: Lindisfarnebooks.

St. Thomas Aquinas. 1948. Summa Theologica. Complete English edition in five volumes. Translated by the English Dominican Province. Notre Dame: Christian Classics from Ave Maria Press, Inc.

Strahovnik, Vojko. 2011. Identity, Character and Ethics. In: Synthesis Philosophica, 51, Vol. 26, Fasc. 1, pp. 67-77.

Škof, Lenart. 2010. Mild gestures: Ethical Pragmatism and the Spirit of Democracy. In Poligrafi, No. 57, Vol. 15, pp. 107-120.

Voegelin, Eric. 1987. The New Science of Politics: An Introduction. Chicago \& London: The University of Chicago Press.

Volf, Miroslav. 1996. Exclusion and Embrace: A Theological Exploration of Identity, Otherness, and Reconciliation. Nashville, Tennessee USA: Abingdon Press.

Žalec, Bojan. 2007. For rational faith and ethical science: on possibility of moral communication between different horizons. In Juhant, Janez \& Žalec, Bojan (eds.), On Cultivating Faith and Science: Reflections on Two Key Topics of Modern Ethics. Berlin: Lit Verlag, pp. 107-120.

Žalec, Bojan. 2008. Possibilities of a universalistic ethics: the capabilities approach. In Juhant, Janez \& Bojan Žalec (eds.), Surviving Globalization: The Uneasy Gift of Interdependence. Berlin: Lit Verlag, pp. 33-58.

Žalec, Bojan. 2011a. Personalism, truth and human rights. In: J. Juhnt \& B. Žalec (eds.), Humanity after Selfish Prometheus: Chances of Dialogue and Ethics in a Technicized World. Berlin: Lit, pp. 29-41.

Žalec 2011b. On not knowing who we are. The ethical importance of transcendent anthropology. In: Synthesis Philosophica, 51, Vol. 26, fasc. 1, pp. 105-115.

Žalec, Bojan. 2014a. Nazism and Stalinism in the light of Kierkegaard's thought. Filozofia, 69, 5, pp. 443-450.

Žalec, Bojan. 2014b. Gnostičnost moderne in totalitarizma ter etika spominjanja v luči solidarnega personalizma in misli Erica Voegelina. In: Čoh Kladnik, Mateja (ed.). Revolucionarno nasilje, sodni procesi in kultura spominjanja : zbornik prispevkov z znanstvenega posveta. Ljubljana: Študijski center za narodno spravo, pp. 130-143. 